\title{
Improving the Economic Status of Negroes Through Laws Against Discrimination: A Reply to Professor Sovern
}

Ralph K. Winter, Jr.

Few domestic problems preoccupy the nation as much as the economic status of the Negro community. The fact that it is relatively low-that the Negro unemployment rate is substantially higher than the white and that Negro income is relatively lower ${ }^{1}$-is not disputed. And there is substantial agreement that bettering the position of Negroes in the labor market-both quantitatively and qualitatively-is a prerequisite to an overall amelioration of their economic status. What means of improving their position in the labor market are feasible or appropriate, however, is not a matter on which there is general agreement. Some argue that preferential treatment in employment ought to be encouraged or perhaps even required in selected circumstances. ${ }^{2}$ Others believe that maintenance of a favorable economic climate, and particularly a tight-high employment-labor market, to be the most, if not the only, effective approach to the problem. ${ }^{3}$ Most sympathetic observers seem to agree, however, that elimination of discrimination against Negroes in employment would result in a substantial improvement of their economic status. Because of this conviction, many of these same persons also eagerly embrace laws which prohibit employers and labor unions from making employment decisions on a racial basis and which provide effective enforcement measures to that end.

In a recent book, Legal Restraints on Racial Discrimination in Employment, ${ }^{4}$ Professor Michael Sovern of Columbia University has comprehensively assessed the role of anti-discrimination and equal

Ralph K. Winter, Jr., Associate Professor of Law, Yale University, received a B.A. degree in 1957 and an LL.B. degree in 1960 from Yale University.

1 See Tobin, On Improving the Economic Status of the Negro, $94 \mathrm{~J}$. AMr. Acad. OF ARTS \&. SCIENCES 878 (1965).

2 The problem of preferential treatment is dealt with in Kaplan, Equal Justice in an Unequal World: Equality for the Negro-The Problem of Special Treatment, 61 Nw. U.L. REv. 363 (1966).

3 See Tobin, supra note 1.

4 The Twentieth Century Fund (1966) [hereinafter cited as SovERN]. 
opportunity programs in improving the position of Negroes in the labor market. It is Professor Sovern's view that such legislation performs a dual function: it prohibits odious conduct-racial discrimination-and thereby makes us a more moral and more virtuous society and also ameliorates the economic status of a group which has suffered much as result of that very conduct. ${ }^{5}$

Many would agree with Professor Sovern that such programs are not based solely on some immutable principle commanding that employment decisions be made only on neutral economic grounds, such as productivity, rather than in part on private, and subjective, prejudices and preferences. Quite apart from problems of administration, a law seeking such an end would be wrong in principle. Many nonmonetary tangibles and intangibles influence business decisions because we subjectively place value upon them, even though, apart from that preference, they seem to have no productive worth. Questions of style and beauty as well as other even less easily defined considerations constantly shape business (and employment) decisions. Matters of individual taste are involved and cannot be eliminated without gross impingement on individual freedom and quite intolerable substantive results. For this reason, if no other, there ought always to be at least a presumption in favor of leaving private conduct free of governmental coercion.

Legislation forbidding use of private non-monetary preferences in economic decisions, therefore, must overcome this presumption in some way, usually on the grounds that the harm caused by the exercise of such preferences outweighs the value of leaving people free to behave as they please. Thus, idiosyncratic behavior, such as discrimination against redheads, which has little "social value" but which also causes little discernible damage to an identifiable group, is permitted because its impact is not sufficient to justify the necessary impingement on individual freedom. Similarly, it can be argued, economic decisions based on monetary considerations, such as not hiring Negroes who lack the requisite qualifications at the going wage rate, must be permitted in spite of the damage to Negroes, first, because it is conduct neutral to race and other subjective considerations, and, second, because it increases total productivity for everyone, Negro and white. But, it can also be argued, racial discrimination in employment has no "social value"-beyond the value of leaving people free to indulge in their private preferences-and causes harm to an identifiable group suffcient to justify governmental intrusion on individual freedom. Anti-

5 See id. at 7-8. 
discrimination programs, according to this view, seem little more than an appication of the old maxim "sic utere tuo ...." for they are the result of balancing the value of leaving people free to engage in whatever conduct they choose against the harm caused by that conduct to others. Professor Sovern argues, therefore, that alleviation of the economic plight of the Negro community-the harm caused by the prohibited conduct-is a prime goal of these programs and that their effectiveness can, and ought to, be measured in large part by reference to statistics indicating the rate of Negro unemployment and the level of Negro income. ${ }^{6}$ Effective anti-discrimination legislation would, in his view, substantially reduce the former and increase the latter.

Whatever their rationale, laws against discrimination in employment are relatively popular and have met with substantial legislative acceptance. Such discrimination-with some exceptions-is now forbidden, in whole or in part, in over half the states and by federal law as well. "Hundreds of federal, state, and municipal agencies," Professor Sovern notes, "now possess powers that can be invoked against racial discrimination in employment." 7 And yet, in spite of this massive involvement of law, the problem of Negro poverty remains with us and shows few, if any, signs of quick resolution. This fact raises serious questions about the role of anti-discrimination and equal opportunity programs as devices to improve the economic status of Negroes. It is Professor Sovern's conviction, and one widely shared, ${ }^{8}$ that the relative ineffectiveness of these programs in this respect stems from their lack of "teeth" as prohibitory law and that their performance can be vastly improved by revising and tightening up enforcement procedures and methods. As a result, he sees no need for a fundamental reappraisal of these programs and limits his examination principally to enforcement procedures and devices. He believes, for instance, that anti-discrimination commissions should be empowered to seek out offenders through spot checking and to initiate proceedings without waiting for a victim of discrimination with sufficient persistence and awareness to pursue legal remedies. ${ }^{9}$ He makes budgetary recommendations ${ }^{10}$ and expresses doubt as to the value of the law's (and the commissions') present emphasis on conciliation as an alterna-

6 E.g., id. at $15,141-42$.

7 Id. at vii.

8 E.g., Norgren \& Hill, Toward Fair Employment (1964); Symposium, 14 Buffalo L. REv. 1 (1964).

9 SOVERN 56.

$10 \mathrm{Id}$. at 57. 
tive to swift enforcement through formalized proceedings. ${ }^{11}$ The federal contractor program receives praise, along with a plea for extension to some presently exempt contracts, as being the most effective antidiscrimination scheme, ${ }^{12}$ while the Equal Employment Opportunity Commission, created by Title VII of the Civil Rights Act of 1964, is scorned as "a poor, enfeebled thing."13 And the book calls for judicial interpretations of the Railway Labor Act and National Labor Relations Act which will impose sanctions upon labor unions which make explicit use of their power in a discriminatory fashion. ${ }^{14}$

I have serious questions about the role of anti-discrimination programs as coercive law and as devices to ameliorate the economic status of Negroes. I assume throughout this article that the presumption in favor of leaving people free of government coercion can be overcome by the kind of showing described above and that the value of individual freedom does not always outweigh the damage caused by the exercise of private preferences, no matter how immoral they seem. That issue, while hardly indisputable, extends far beyond the problem of discrimination in employment. But the conclusion that the individual freedom involved is in this instance outweighed should not be the end of the matter. There is, first of all, a very substantial question as to the extent to which the present economic status of the Negro community can be attributed to employment discrimination. While a recitation of the statistics of Negro poverty is surely relevant to a discussion of discrimination in employment, it just as surely does not prove a significant causal relationship. In light of the relatively inferior training and experience and the general educational level of Negroes in the United States, the absence of such statistics would be startling. And to assume that there is a substantial causal relationship is doubly dangerous, for it not only exaggerates the necessity of outlawing discrimination by overstating its impact but also unrealistically inflates expectations as to the elimination of economic hardship through enactment of such laws. Second, even if, indeed, especially if, discrimination in employment is as pervasive as suggested and is a substantial cause of Negro poverty, it still may be unrealistic to hope to eliminate it through litigation and thereby to improve the economic status of $\mathrm{Ne}$ groes to any substantial degree.

Such objections, however, while by no means insubstantial sources of my own skepticism, only partially undercut the arguments of the

11 Id. at $57-58$.

$12 I d$. at $103-42$.

$13 \mathrm{Id}$. at 205.

14 Id. at $143-75$. 
more vigorous proponents of anti-discrimination legislation. For if little value is placed on the individual freedom involved in racial discrimination, the cost of such laws may still seem relatively minor, and vigorous enforcement quite appropriate, even though the necessity is unproven and the gains realistically expected not great. But the loss of individual freedom may not be the only cost of vigorous enforcement, particularly enforcement with a view to substantially improving the economic condition of the Negro community. One reason why antidiscrimination programs are so popular is that they not only seem to reach the right result but also do so by insuring that people act according to our canons of decent behavior. Thus, the position of Negroes in the labor market can be improved, and at the same time employment decisions will be governed by the principle of color-blindness. Professor Sovern is able, therefore, to promise the alleviation of economic hardship while vigorously attacking quota or preferential systems on principle. ${ }^{15}$ It is my contention that because of the complex nature of employment discrimination and the problems of proof involved in proving that discrimination, these goals are in fact inconsistent ends of coercive law and that we cannot both effectuate the principle of color-blindness in employment and substantially improve the economic status of Negroes through laws against discrimination. I will argue, moreover, that the economic harm generally attributed to discrimination either need not result from it or is not amenable to the kind of regulation fair employment programs provide. This being the case, I have grave doubts about the wisdom of fair employment programs generally.

\section{Discrimination in Employment}

The word discrimination is easily used indiscriminately. It has an evil connotation which conveniently provides justification for its own prohibition as well as an emotionally satisfying reason for a distasteful result, such as Negro poverty. If the temptation to attribute too much harm to "discrimination," and to avoid further delineation merely by repeating the word over and over again, is attractive to scholars, ${ }^{16}$ it is understandably irresistible to politicians. So it is that most anti-dis-

15 Id. at 211-12.

16 In Sovern, Norgren \& Hill, op. cit. supra note 8, and the symposium in 14 Buffalo L. REv. 1 (1964), for instance, the advocates of vigorous enforcement of fair employment programs almost never distinguish between situations in which an employer acts from a personal bias and those in which he is responding to a market pressure which, however unfortunate it may be, makes Negro labor more expensive than white. See notes 23-31 infra, and accompanying text. 
crimination statutes and regulations fail to describe with precision what kinds of conduct or motives are within their ban and merely prohibit employment decisions by employers and unions which are based on race.

Plainly, labor markets-the employment decisions of employers"discriminate" against Negroes, that is, they distinguish between Negroes and whites to the detriment of the former. That much is proven by the statistics. But that view attributes all Negro unemployment and poverty to employment discrimination and surely is not what the statutes mean. A review of the situations in which employers choose whites over Negroes in hiring or determining terms and conditions of employment is, therefore, necessary.

(1) The employer is motivated by racial animus. There are only two circumstances in which this has an effect: a) when he is unable to determine-on the basis of particularized information or generalizations as to groups - which of several candidates has the greater marginal productivity and b) when he knows the disliked candidates (Negro) have a greater marginal productivity than the preferred (white). In all other circumstances racial animus, no matter how virulent, is irrelevant, since economic considerations alone dictate choice of the preferred. Effective racial discrimination, therefore-in (a) when his animus causes a wrong guess and in (b) when he deliberately overrides monetary considerations-imposes a cost on an employer and at some point the cost of satisfying his prejudice will be greater than he is willing to pay. ${ }^{17}$ When that occurs, he will sell the business to a less prejudiced person or hire from the disliked group.

(2) The employer does not hire Negroes because other employees prefer not to work with them. ${ }^{18}$ In those circumstances white workers, when faced with a choice between otherwise identical jobs, are more likely to choose those in which they do not work with Negroes. (The degree of taste for discrimination matters not at this point in the analysis. They may be just a little bit more likely to prefer the jobs without Negroes or very much more.) Negroes will be hired only when the whites are paid more than in the all-white firm (they get cash in exchange for failing to satisfy their racial preference) or when the marginal productivity of a predominantly Negro force is the same or higher than a predominantly white force. Employee discrimination, therefore, may create incentives for segregated work forces.

(3) The employer does not hire Negroes because his customers will

17 See Becker, The Economics of Discrimination 31-46 (1957).

18 See $i d$. at $47-55$. 
not like it, i.e., consumer discrimination. ${ }^{19}$ If Negro labor is cheaper than white, the employer may be able to lower the price of the services or whatever he provides-that is, pay the consumer for failing to satisfy his racial preference. This form of discrimination probably occurs, I would suggest, most often in establishments in which employees and customers must be in close contact as, for instance, barber shops, beauty parlors, or neighborhood bars.

(4) The employer does not hire Negro applicants because as a group they are generally less qualified than the white applicants as a group (because of education, etc.) and he does not engage in costly individual testing. This is probably very common since most employment decisions are based in large part merely on guesses or generalizations rather than on hard information about the particular person. Segregated schooling, for one example-whether de facto or de jure -may permit the formation of generalizations as to the quality of education the two groups receive. An employer might, therefore, quite rationally refuse to hire the graduates of a particular high school-or to hire Negroes because in the particular locality they have all attended that school-and thereby effectively discriminate against Negroes. ${ }^{20}$ In that situation the cost of determining which Negroes are "worth" the going rate might be quite high. Here Negroes must offer themselves at a wage low enough to justify individual testing or to off-set the superior qualifications of whites as a group.

(5) The employer hires no Negroes because none are available through his traditional recruitment sources and seeking out qualified Negro applicants imposes a cost. This is also a common situation since the practice of workers referring friends, relatives, and neighbors to the employer, and of his drawing heavily upon this source, is quite common. ${ }^{21}$ And an employer satisfied with the quality of help so available would be understandably reluctant to experiment with new sources which might not, and I suspect often do not, work out. Again Negro labor must be sufficiently more productive or less costly and give employers incentive to seek it out.

(6) The employer makes employment decisions on the basis of nonmonetary but also non-racial criteria, such as nepotism, which in fact

19 See $i d$. at $56-62$.

20 NORGREN \& Hill, op. cit. supra note 8, at 18, note the practice of recruiting from schools in white neighborhoods but, as usual, don't concede a possibly sound economic reason for the practice. One wonders whether the authors, in making their employment decisions rather than other people's, always religiously fail to distinguish between the quality of education received at various institutions.

$21 \mathrm{Id}$. at 18. I take it there is no real dispute that this is not only a common practice, but one commonly not intended by the employer, at least, to exclude Negroes. 
result in the exclusion of Negroes. As in situation (1) (employer bias), the cost of satisfying these preferences will at some point be greater than he is willing to pay.

(7) A union imposes conditions on the employer which explicitly compel him to make decisions on a racial basis or in fact operate to discriminate against Negroes. An example of the former is insistence that Negroes be limited to certain jobs while the latter is exemplified by seniority lists which, because established on a plant, departmental, job, or other level, tend to leave Negroes at the bottom. A more effective form of union discrimination results from the device of the exclusive hiring hall. In those circumstances economic self-interest and racial animus, instead of working against each other, combine and form a virtually impenetrable barrier to Negro employment. Because the maintenance of high wages requires in any event the exclusion of potential competitors, barring entry to Negroes can simultaneously satisfy prejudice and maintain high wages for union members. ${ }^{22}$

(8) The employer does not hire Negroes because those who offer themselves are not qualified at the going wage rate, that is, better qualified applicants are available at that wage.

At which of these situations, then, is the typical anti-discrimination statute aimed? Surprisingly, given the time these statutes have been in effect and their seeming popularity, there is no clear answer, in terms of either case law, commentary, or legislative declaration, to this basic question. Plainly, situation (1) (employer bias) involves a violation of any such legislation or regulation. Altogether too plainly perhaps, for it is quite apparent that these programs are based on a model in which the prohibited decision is generally made by a racially biased employer -and, less often, by a similarly inclined union. Political forces, as well as practical considerations relating to administration, have probably compelled this statutory approach since "discrimination" may lose its political appeal as a target for legal prohibition when analyzed in detail. Whatever the motive, the failure to look beyond this simplistic model has had undesirable consequences. It has sired a great deal of legislation and administrative regulation which is terribly difficult to oppose without seeming a racist but which, at best, is altogether too vague, both in principle and practice.

One reason the model seems inappropriate is that the racial animus of employers is probably not a primary source of economic harm suffered by Negroes as a result of racial discrimination. Many employers may be racially biased. But how often this prejudice actually affects 
employment decisions, that is, causes employers to sacrifice monetary considerations, is another question. Employing a work force in accordance with personal prejudice rather than economic considerations can be very costly and even disastrous to the effective operation of a firm. Such behavior is probably most likely to occur in non-profit organizations, regulated industries, monopolies, family companies, or small individual proprietorships. ${ }^{23}$ In the latter two situations part of the "gain"-a "loss" in monetary terms-from economic activity is the ability to hire one's relatives or to choose one's work partners. Except for small proprietorships, however, these examples do not represent the norm. The very small firms are in any event the least amenable to legal regulation. The cost of litigating with each individually would be enormous, and they may not in fact offer that much opportunity for substantial increases in Negro employment.

The impact of employer discrimination, therefore, is probably less than one might anticipate and may often be overestimated because economic discrimination is confused with prejudice. Common experience suggests that in a firm of any size management's prejudice is more likely to have an impact in the country club, where close contact with Negroes may seem a larger threat, than on the assembly line, where little contact is to be anticipated..$^{24}$ Discrimination in these circumstances is most likely to be the result of the conduct of lower supervisory employees such as foremen, who control hiring for certain job classifications. But the impact here will not be significant unless considerable discretion to sacrifice the interests of the firm for personal considerations has been delegated. To the extent that economic forces do not limit this discretion, the reason must be that good unbiased foremen are hard to come by in the area and the loss caused by their discrimination is less than might result from attempting to compel them or any potential replacements to enter into distasteful associations. No matter what the law of agency says, therefore, this situation must be treated, for purposes of analysis, as a case of employee, rather than employer, discrimination. ${ }^{25}$

It is hard to imagine, moreover, a substantial number of employers discriminating against Negroes because of a racial bias without almost every other kind of discrimination (employee discrimination, consumer discrimination, etc.) coming forcefully into play. Indeed, al-

23 Cf. Becker, The Economics of Discrimination 35-39 (1957).

24 Employer bias, therefore, at least in terms of sizeable firms, is more likely to have an impact on better trained Negroes, whose qualifications might put them in close contact with management, than on those who in any event are eligible only for lower paying employment.

25 See notes 26-30 infra and accompanying text. 
though we cannot be certain, these other forces, particularly discrimination by white employees, may often play the foremost role. And surely the employer who doesn't want to hire Negroes solely because of his own bias is in a better position to appear in compliance with such a law than one who must respond to employee and customer prejudice. The former can engage in token hiring without totally abandoning his bias while the latter may be penalized substantially for deviation from local standards. The model, therefore, seems wrong in assuming that considerable discretion exists in employment decisions. Employers may in fact be largely circumscribed by forces which permit the exercise of discretion only at a price.

Just as there is a tendency to overestimate the impact of employer bias, the effect of (2) (employee discrimination) and (3) (consumer discrimination) is often underestimated. The elimination of racial discrimination is often visualized in terms of great confrontations, of Lester Maddox and his restaurant or George Wallace and his schoolhouse door, of people specifically intending to exclude Negroes from some activity. Thus, when Negroes make gains in employment and there are few dramatic reactions from whites, such as strikes or consumer boycotts, it is often assumed that employee and consumer discrimination are not a bar to Negro advancement. ${ }^{26}$

Some weight must be accorded such observations. But they must be viewed in context. First, most gains have been largely the result of voluntary action for existing anti-discrimination programs-with the exception of the federal contractor program which, it is worth observing at this point, pays employers to hire Negroes ${ }^{27}$ - have simply not been enforced. These gains, therefore, having occurred in an era of decreasing bias-until perhaps the last couple of years-and increasing Negro capability, may prove only that employers will in fact hire Negroes as employee and consumer discrimination abates. They may, in short, prove the lack of a need for laws prohibiting employer discrimination. Second, the lack of frequent and hostile reactions from whites is in no small part traceable to the noticeable timidity of the attack on union discrimination. ${ }^{28}$ When a concerted effort to break the hold of the building trades unions over jobs in the construction industry is made, for instance, we can make a more accurate assessment of the impact of employee discrimination.

Finally, and most important, many of the results often attributed to discrimination may stem from conduct which, because it is not engaged

26 See Norgren \& Hilt, op. cit. supra note 8, at 30-31.

27 See notes 68-80 infra and accompanying text.

28 See notes 53-67 infra and accompanying text. 
in with a specific or hostile intent to avoid or exclude Negroes, is not highly visible and will never surface in the form of strikes or other dramatic acts. When an activity necessarily involves continuous association with other people, many will seek means of engaging in it which permit them to associate with those whom they like and with whom they believe they have much in common. No one can deny that employment is such an activity and that many people will treat the personal associations involved therein as an important factor to be weighed in determining what job to take. A preference for working with people with whom one has much in common may well induce many to sacrifice monetary considerations for the sake of pleasing personal associations. In many cases, therefore, homogeneous work forces are likely to be cheaper for employers to maintain than heterogeneous ones. And in the United States, since white workers often prefer to work with Negroes less than other Negroes do, work forces, ${ }^{29}$ even in areas in which racial tolerance prevails, may divide along predominantly-but not necessarily exclusively-racial lines.

The same considerations are applicable in circumstances in which customers must associate with employees and firms treat pleasing relationships as part of their stock in trade. Barber shops, beauty parlors, and neighborhood bars again may be examples of situations in which satisfaction from personal associations interacts with price to determine which firms get particular customers.

An employer who disrupts traditional hiring policies to hire $\mathrm{Ne}$ groes, therefore, may face great risks. First, he will lose in a short time those employees and customers with a specific bias. Over the long run, however, if personal associations are part of his stock in trade in attracting employees or customers, he may find he is not attracting new employment applicants or new customers at the normal rate, not as much because they explicitly dislike or are hostile to Negroes as because associations with persons with whom they believe they have more in common or otherwise prefer are available elsewhere. The net result will be a competitive advantage for his business rivals.

To be sure, the impact of this process will vary from firm to firm and area to area, and no one will be able to predict in advance the precise effect the hiring of Negroes will have. But the employer may be in the best position to make such a judgment, and he is in any event the one who will be most harmed if the impact is greater than anticipated. In any case it is wrong to argue that because there have not been many explicitly hostile reactions from other employees as a result of hiring Negroes, employee discrimintion does not exist.

29 Becker, The Economics of Discrimination 48-50, 126-29 (1957). 
One unspoken premise of anti-discrimination programs may be that employers are in some way insulated from the impact of employee or consumer discrimination. The factual foundation for this premise is nowhere laid, and it seems to me that on this issue the burden of proof rests with the proponents of the legislation. If anything, the evidence is that employers are very sensitive to such forces. Why, for instance, to use an example from Professor Sovern's book, does the Lockheed Aircraft Corporation discriminate more in its Marietta, Georgia plant than elsewhere? If employers are so insensitive to employee racial preferences, they would not, as they often do in the South, provide separate facilities at what may be a substantial cost. In any event, such a premise may prove too much, for if employers are in fact insulated from such pressures, the impact of employment discrimination must be far less than the advocates of such legislation have maintained.

A more serious argument is that anti-discrimination programs apply equally to all competitors, and no one competitor can gain an advantage, except through the kind of sporadic non-enforcement which occurs under any law applicable to business, including, for instance, the collection of social security taxes. That is not the case, however. Anti-discrimination programs-according to their avowed purposein no way command that once one competitor hires someone from the disliked group all others must do the same. The duty is to refrain from discrimination, not to deliberately hire from the disliked group. But there may not in fact be many qualified Negroes or members of other minority groups available to some competitors, and there is no particular reason to believe these potential employees themselves have tastes which will lead them to desire jobs in all these firms. An attempt to equalize the competitive impact necessarily contemplates establishing a minimum for some firms and a maximum for others-in short, a quota system and preferential hiring. Equalization of the competitive impact, therefore, requires not enforcement of the principle of colorblindness but abandonment. And that may ultimately be as much the case with the Negroes' exercise of choice as to where they will work as it is with the employers' choice as to whom they shall hire.

In any event, equalization, even if we were willing to accept quota systems, is not possible. Each employer faces a variety of degrees of tastes for discrimination in his employees and customers, and even a quota system carries with it no assurance that each firm will be affected equally with respect to the particular degree of employee or consumer discrimination it faces.

To the extent that anti-discrimination programs seek to control employers' responses to consumer or employee discrimination-and 
they must so try if there is any hope of their substantially improving the economic status of the Negro community-serious objection can be made to them. First, the unrealism of the attempt to use such programs as anti-poverty schemes becomes apparent. In the long run, because consumers and employees are left free, these programs are not likely to be effective since the principal beneficiaries may be the firms least touched by the law rather than Negro workers. To be sure, the latter will be helped, but hardly to the anticipated degree, and at a cost of the disruption of many markets.

Second, the moral thrust, as coercive law at least, of anti-discrimination programs-the hoped-for decrease in racial discrimination and the formation thereby of a more moral and virtuous society-seems blunted, because the persons engaging in such discrimination-consumers and employees-are not subject to legal restraints while nondiscriminating parties-employers-are. Their thrust, instead of resting in part on a judgment that racial discrimination is immoral conduct, must be bottomed almost entirely on a desire to help the Negro community economically. And that goal is a very different proposition, since it by no means requires adherence to a policy of color-blindness. Nor is it clear to me that in the absence of a specific bias against Negroes, the law ought to stop people from seeking out associations which please them even though relative degrees of de facto segregation may be the result. The imposition of heterogeneity by law would, I suspect, be as distasteful to Negroes as to whites in the long run.

Finally, imposing sanctions on employers responding to consumer or employee discrimination will have the same effect as the imposition of any cost on business. Total production and total employment will be less, for Negroes and for whites. This must be weighed against the gains to be anticipated from such action and against the claims that anti-discrimination programs actually increase economic activity. ${ }^{30}$

Imposing sanctions in situations in which hiring Negroes imposes a cost on employers not borne when whites are hired also seems a bad precedent. If (2) (employee discrimination) and (3) (consumer discrimination) are violations, then why isn't (4) (stereotypy rather than individual testing), no matter how factually justified the employer's belief in the superior qualifications of white applicants as a group or how costly individual assessment may be? And if that answer is affirma-

30 That discrimination in employment decreases economic activity is certainly the case. See id. at 14-16. But it does not follow that when employers are forbidden by law to respond to discrimination by consumers and employers, the effect of that discrimination will disappear. In fact, a further decrease may be the case. 
tive, why isn't (5) (no Negroes available through traditional recruitment sources) illegal, and why not a rule compelling employers to seek out qualified Negro applicants? Professor Sovern seems to suggest that a proper anti-discrimination program might contain such a mandate..$^{31}$ This seems to me inconsistent with his quite explicit disposal of "compensatory discrimination" schemes and quota systems and with the principle of color-blindness which is at the heart of the anti-discrimination programs themselves. I am troubled, moreover, by the automatic rejection of stereotypy, rather than particularistic individual assessment, as a relevant factor in employment decisions. All kinds of employers, from corn flakes manufacturers to law schools, engage in it. A belief that the graduates of one school, for instance, are generally superior to those of another is hardly irrational and should not be thought reprehensible. And in many areas it will be the case that potential Negro applicants as a group simply do not have the educational background or experience which generally predominates in the white group. Individual assessment may be very costly-sufficiently so, it might be added, that employers who attempted it might hire fewer total employees. Since employers can in any event more cheaply avoid such costs by adopting quota systems, I suspect that such a rule invites the very kind of hiring policies which Professor Sovern explicitly deplores.

I am not arguing that a court or agency directly faced with a case raising these issues ought to restrict application of anti-discrimination legislation solely to discrimination resulting from the racial animus of an employer. Decisions based on (2), (3), (4), or (5), although not stemming from the employer's bias, are in fact based on race. The adjudicatory process, moreover, is simply not sufficiently refined to separate out the various motives which might be involved. In terms of the evidence likely to be available in the typical case, the various situations are virtually indistinguishable, and a serious attempt to distinguish them will render enforcement even less even-handed. ${ }^{32} \mathrm{~A}$ court or agency cannot, moreover, wait and see how much business the corner barbershop loses. Enforcement of anti-discrimination legislation, therefore, particularly if a substantial improvement in the economic status of the Negro community is the goal, may depend upon a broad interpretation of its prohibitions. An anti-discrimination commission might, however, take these issues into consideration in determining the right mix of conciliation and formalized enforcement. And legislatures, when deciding whether and what form of legislation is appropriate, should face

31 Sovern 142. But see Becker, The Economics of Discrimination $42-43$ (1957).

32 See notes 35-38 infra and accompanying text. 
up to these problems. Surely, they also deserve some form of recognition from observers such as Professor Sovern.

Situation (7) (union discrimination) violates many anti-discrimination laws when it stems from racial animus, as for instance, when a union prevents the hiring of Negroes. Professor Sovern would also extend the legal bar to nepotic systems, such as those engaged in by the construction trades, but because he believes this an abuse of power rather than a violation of the color-blindness rule. Other monopolistic barriers, such as seniority lists or exclusionary wage rates, fall outside the prohibition. ${ }^{33}$

Only (6) (decisions based on non-monetary but also non-racial considerations, e.g., nepotism) ${ }^{34}$ and (8) (Negroes not qualified at going rate), then, involve clearly permissible conduct. This is not to say the rest will necessarily be held illegal, for what the anti-discrimination programs prohibit is unclear. It is to say, however, that the premise that such programs can significantly improve the economic status of Negroes may create pressures impelling decision makers beyond ( $\mathrm{I}$ ) (employer bias). And it is further to say that Professor Sovern's twin policies, color-blindness and helping Negroes economically, do not, as he seems to suggest, consistently pull in a single direction. Quite the contrary, for in a significant number of cases substantial tension exists between them.

\section{Proof of Discrimination}

Thus, in spite of the fact that racial discrimination in employment has been illegal for several years and in a large number of states, it is unclear what factual situations violate the law. It comes as no surprise, therefore, to learn there are few standards to which we can turn for guidance as to what kinds of proof are sufficent to establish those facts. One analogy might be the anti-discrimination-on the basis of union membership-provision of the National Labor Relations Act, section $8(a)(3){ }^{35}$ But this provision comes into play most often in discharge rather than hiring cases and thus involves affirmative employer action which usually requires some form of explanation. As far as hiring is concerned, membership in a labor organization is hardly as obvious as race, and refusals to hire for that reason may well involve provable investigatory action by the employer. Another guide might be found

33 See SOVERN 70-73.

34 Nepotic systems are apparently acceptable so long as they are not based on some form of monopolistic control as when a labor union is involved. That is perfectly rational since when competition has free play, such systems can have only limited impact.

3529 U.S.C. \& 158(a)(3) (1964). 
in other civil rights legislation, such as public accommodation laws. But the problems of proof are obviously different and no analogy is possible. Thus, not only are the statutes virtually silent on the issue, but we cannot look to related fields for analogous standards.

In each case the principal factual issue should be the employer's motive. In some cases there may be direct evidence, either testimonial or real, indicating discrimination based on the racial hostility of the employer, such as a statement by the employer indicating he refused to hire a particular person because of his race. Such cases will probably be quite rare, however. In all other cases violations must be made out on the basis of circumstantial evidence, that is, evidence from which an inference of an act stemming from an illegal motive may be drawn. One example is evidence of racial bias on the employer's part. The existence of such a bias might permit the drawing of an inference that he has discriminated against Negroes in employment decisions. Such an inference is hardly mandatory, however, for, as argued above, there is no particular reason to believe that such prejudice always affects business judgments. Whether the inference should be drawn depends, therefore, upon the surrounding circumstances, such as the number of Negroes employed by the firm, the positions they hold, the number of seemingly qualified Negroes in the particular labor market, etc. Another example might be the rejection of three Negro applicants for three apparently less qualified whites. The trier might attempt to infer from this conduct that the employer acted from racial animus. Again, the inference is not the inevitable offspring of the facts proven. That the trier finds the particular Negro applicants were better qualified than the whites hardly proves the employer shared this belief at the time he made the decision. He may just be stupid. He may, moreover, have rejected the Negroes because of (2) (employee discrimination), (3) (consumer discrimination), (4) (stereotypy rather than individual testing), or (6) (non-monetary and non-racial considerations such as nepotism). Again, surrounding circumstances may clarify the motives involved, but the number of permissible inferences renders enforcement of anti-discrimination programs virtually impossible unless at least situations (2), (3), and (4) are held to involve violations. Behavior such as nepotism need not be held a violation, however, since a trier of fact can determine quite easily the legitimacy of an employer's claim that he was so motivated..$^{36}$ In any event, while cases involving

36 Whether problems of proof necessitate holding (5) (no Negroes available through traditional recruitment channels) a violation is not clear. On the one hand, the fact that such channels are used to the exclusion of others seems reasonably susceptible of proof. On the other, constant use of recruitment methods which produced no Negro applicants might be the resuit of a desire, based on a racial animus, to avoid hiring them. 
these kinds of circumstantial evidence will arise, I suspect that even if a violation were found in every case, the impact in terms of increased Negro employment would not be great.

In the main, if anti-discrimination programs are to result in a substantial increase in Negro employment and income, enforcement tribunals must rely upon the lack of Negroes in certain firms or job classifications within those firms to prove violations. Professor Sovern thus emphasizes the importance of empowering enforcement authorities to initiate spot checks and to require reports indicating the racial characteristics of employees. And, again, an inference that situations (2), (3), (4), or (6) - and in this case (5) (Negroes not available through traditional recruitment sources) also-are present seems as viable as an inference of (1) (employer bias). The weight to be given to the absence of Negroes will of course also vary according to the number residing in the locale, the number holding similar positions in other firms, etc. And its legal impact will certainly be determined in large part by the allocation of the risk of non-persuasion, a point which may be of considerable importance with respect to the government contractor program. As important, however, indeed, perhaps most important, is the predisposition of the trier to believe that racial discrimination (as defined through statutory interpretation) is a prime cause of Negro unemployment and poverty.

It is not surprising, therefore, to find Professor Sovern saying:

What all this comes down to for present purposes is that an employer with no Negro employees in an area with significant numbers of qualified Negroes cannot be sure how a charge brought against him would come out if taken to public hearing. He would be well advised, then, to conclude a settlement agreement that required him only to broaden his recruitment base. ... This does not, it should be emphasized, entail discrimination in favor of Negroes. It is intended merely to bring to their attention openings they would not be likely to learn about if employers persisted in their old recruitment methods. When they apply, the employer remains entirely free to pick the best man without regard to color. ${ }^{37}$

What all this in fact comes down to is that an employer in those circumstances "cannot be sure" the trier of fact will correctly determine whether there are "significant numbers of qualified Negroes" in the area or whether, when his choices are reviewed, the trier will agree that he picked "the best man." Indeed, if a sizable operation is involved 
and a position requiring a lot of education is not, an employer may not have even considered going into the detail necessary to determine as an adjudicative fact-which is what he will have to be concerned about if enforcement proceedings are instituted-whether there are "qualified" Negroes in the area or whether one applicant is really better than another. Professor Sovern's view of hiring seems unrealistic, in sharp contrast to his appraisal of the tactical position of an employer faced with a charge of discrimination by an energetic tribunal. The cost of making a particularistic individual assessment of each applicant, the cost of proving to a trier of fact that the assessment. was made, that it was correct or at least made in good faith, and the cost of adverse publicity can often best be avoided by hiring some Negroes, that is, by establishing a quota. Professor Sovern hits closer to the mark when, in discussing compliance reporting schemes, he says:

The risk that companies will engage in quota hiring in order to impress government officials that they are not discriminating is less easily dismissed. It is, however, a risk which attends any equal opportunity program to some extent . . . . The reasons should be obvious-if a company has about the "right" proportion of Negroes, it is virtually invulnerable to a charge of discrimination .... Quota hiring, then, is in the nature of insurance and probably cannot be forestalled altogether ....38

My point is not that the lack of the "right" proportion of Negroes is likely to be held sufficient proof under most-excepting again the federal contractor program-anti-discrimination schemes, as they are presently administered. The burden of proof is usually upon the complainant, and the tribunals themselves are probably unconvinced that a lack of the "right proportion" of Negroes proves racial discrimination. Nor am I arguing that discrimination by a biased employer can never be proven. But such cases will be insignificant in terms of putting substantial numbers of Negroes to work. In the cases that will bring about such results, however-those in which the only hard evidence is the absence of Negroes in a firm or job classification within that firm-an enforcement tribunal cannot grant relief without effectively imposing a quota or preferential hiring system. Such rulings are more than findings of fact in particular adjudications; they are for practical purposes rulings of law applicable to all similar employers in the same labor market. Since quotas avoid litigation and are often less expensive than the alternative of individual assessment-which re-

$38 I d$. at 124 . 
quires testing that satisfies the enforcement tribunal as well as the employer-such rulings make quotas altogether too attractive. My point, therefore, is that an anti-discrimination program which puts substantial numbers of Negroes to work through the coercion of the law, that is, an "effective" program, will do so by inducing employers to engage in quota or preferential hiring.

\section{State and Federal Legislation Against DISCRIMINATION BY EMPLOYERS}

In almost every case such anti-discrimination legislation prohibits employment decisions made on a racial basis and entrusts the principal, or at least initial, enforcement responsibilities to an administrative commission. For the most part, the model upon which the legislation is drawn is that described above: a discriminating employer whose conduct is amenable to legal regulation. There is a considerable variance in enforcement powers between jurisdictions, as, for instance, in the ability-and, in some cases, the willingness-to initiate proceedings without an injured complainant.

Deservedly ranked among the least powerful is the Federal Equal Employment Opportunity Commission. After receiving a sworn charge from an alleged victim of racial discrimination, the Commission is directed by Title VII of the Civil Rights Act of 1964 to investigate the matter with a view to determining whether "there is reasonable cause to believe that the charge is true." 39 If that determination is affirmative, an attempt "to eliminate any such alleged unlawful employment practice by informal methods of conference, conciliation, and persuasion" 40 must be made. If that fails, the Commission's terminal responsibility is to so inform the complainant who may then bring a law suit in a federal court. ${ }^{41}$ Professor Sovern does not understate the matter when he guesses that "many victims ... will regard it [being informed that informal methods have failed] as the end of the matter." 42

Title VII is not entirely toothless, however, for if the case is "of general public importance," the Attorney General may be permitted to intervene in an action by an individual complainant. ${ }^{43}$ More significant, section 707 empowers him to sue on his own when he "has reasonable cause to believe that any person or group of persons is engaged in a pattern or practice of resistance to the full enjoyment of any of the

3942 U.S.C. § 2000e-5(a) (1964).

4042 U.S.C. $\$ 2000 \mathrm{e}-5(\mathrm{a})$ (1964).

4142 U.S.C. $\S 2000 \mathrm{e}-5(\mathrm{e})(1964)$.

42 SOVERN 74.

4342 U.S.C. \& 2000e-5(e) (1964). 
rights secured by this title, and that the pattern or practice is of such a nature and is intended to deny the full exercise of the rights herein described ...." 44 The obscurity as to the legal content of discrimination as well as to what evidence is necessary to prove its existence is hardly dispelled by requiring that it be a "pattern or practice." An employer who regularly refuses to hire Negroes solely because of his own bias or that of employees or customers, or because of a desire to avoid the costs of individual testing, and who, being so motivated, will regularly do so, is surely engaged in a "pattern or practice." Since the principal evidence again may be the absence of Negroes in certain firms or jobs, it is difficult to discern what cases of discrimination are excluded, that is "single, insignificant, isolated acts of discrimination by a single business ..." in the words of the then Senator Humphrey. ${ }^{45}$ Section 707 applies to individual employers, but it seems plain that an "isolated" or "sporadic" act would never be held a violation of the law. Discrimination is not something, after all, practiced only on the third Tuesday of every month ending in "r." It is itself a "pattern or practice," and section 707 hardly limits the discretion of the Attorney General through use of that phrase.

Section 707, therefore, has quite undefined potentialities and may well be a device which, if broadly construed by the courts and frequently invoked against employers by the Attorney General, will lead to quota hiring within entire labor markets. It can serve, however, to mitigate one difficulty inherent in typical anti-discrimination laws. The latter are usually invoked principally against individual employers, and to the extent these firms are motivated by (2) (employee discrimination), (3) (consumer discrimination), or (4) (stereotypy rather than individual assessment), compliance puts them at a competitive disadvantage since hiring Negroes imposes a cost not borne by competitors unaffected by similar legal sanctions. Section 707 , by permitting and encouraging suits against groups of employers, may contemplate naming all competitors in a local market as defendants. But, as argued above, since the inequity of individual enforcement is not removed unless the extra costs imposed on each competitor are proportional, sanctions under the provision in question may not really be equalized unless they impose quotas on each employer.46 All competitors, moreover, are not necessarily to be found within a single local market. The impact of Title VII as a whole, however, must be left for future determination.

Professor Sovern concludes that the performance of anti-discrimina-

4442 U.S.C. § 2000e-6 (1964).

45110 CoNG. REC. 14270 (1964).

46 See notes 26-30 supra and accompanying text. 
tion laws and the commissions established under them is "disappointing when measured against either their potential performance or the job to be done ... ."47 Given his premises as to the role of these laws, that is indeed the case. The New York Commission, for instance, the busiest in the country, armed with a statute more coercive than most and a budget (1963-64 fiscal year) of $\$ 1,666,039$ (9\& per citizen of New York), ${ }^{48}$ handles less than 600 employment complaints a year. ${ }^{49}$ And yet New York still has substantial Negro unemployment. ${ }^{50}$

As a result, Professor Sovern recommends tightening up, legislatively and administratively, in this area. But he expects too much from these programs as coercive applications of law. After all, there is good reason for commission members to be cautious about vigorously applying the statutory ban to situations in which the employer in question has not acted from a bias of his own or about reading too much into the absence of Negroes in particular firms. And short of that, there may be no effective means of substantially increasing Negro employment through such laws, even with the adoption of Professor Sovern's recommendations. Nor is it clear that the attainable results are at all commensurate with the governmental resources he would expend, particularly since many other devices, and less coercive ones at that, are available. This does not take into account, moreover, the cost of record-keeping, reporting, inspections, hearings, etc., imposed on affected businesses under more coercive schemes which, if substantial, would further reduce total productive employment.

In any event, these programs, if we are to have them at all, cannot be effective in Professor Sovern's sense unless they become in large part preferential hiring schemes. If they serve a useful function, it is, and ought to be, morally educative rather than legally coercive. As such, they encourage employers to review their assumptions about hiring policies and perhaps to experiment. Given the inevitable uncertainties as to the qualifications of individual candidates, as to the reactions of consumers and other employees, and as to the risks of departing from traditional recruitment sources, litigation seems too unrefined a device to be let free in this area. The advocates of such legislation, moreover, have consistently stressed only the need to help Negroes economically and have never faced up to the serious problems vigorous enforcement would create. The case for such enforcement is for that reason essentially unproven.

Furthermore, because these programs affect the moral sense of the 
community, or at least give a sympathetic employer an excuse-although this is of secondary importance, I suspect ${ }^{51}$ - they may reduce, without coercion, the number of situations in which other workers or customers will impose a cost on an employer for hiring Negroes. Professor Sovern recognizes this but tends, I think, to underestimate it in his urge to make these programs more effective as coercive law. My own belief is, and nothing in his book leads me to conclude otherwise, that the educative impact is probably the effective outer limit of these laws - so long as they are in fact non-discriminatory-in substantially improving the economic status of the Negro community. Beyond this, the public and private resources necessary sharply increase, as does the amount of coercion required, while the returns diminish correspondingly. I do not mean to assert that Professor Sovern's recommendations would accomplish nothing. It is my view that some results would be forthcoming but at a high cost and that the programs would increasingly involve preferential hiring.

Conciliation, then, as in the present Title VII, is properly emphasized by the existing legal structure. It provides a device which maximizes the educative function and minimizes governmental impingement on private conduct. Indeed, overemphasis on resort to coercive machinery may well destroy the symbolic value of anti-discrimination programs as appeals for civilized conduct. For one thing, vigorous enforcement would lead to preferential rather than non-discriminatory hiring, and if that was generally appreciated by the body politic, as it eventually would be, the educative value of these laws on the basic moral issue would be destroyed..$^{52}$ For another, to the extent that the law seeks compliance through coercion, it invites those affected to focus on problems of enforcement-and avoidance thereof-rather than on the basic issue of the morality of racial discrimination. Unless society faces that basic issue and resolves it against prejudice, laws against discrimination in employment, particularly in view of the importance of employee and consumer discrimination, will in any event fail to achieve their purpose.

\section{Regulation of Union Discrimination}

Discriminatory practices of labor unions have been increasingly attacked in recent years by new legislation, such as the Civil Rights

51 Employees or customers with association preferences not related to a specific intent to avoid Negroes are not likely to care whether the employer has an excuse for hiring Negroes because they are not aware that they are discriminating against them.

52 Kaplan, supra note 2, at 379-80. 
Act of 1964, as well as by interpretation of existing statutes. ${ }^{53}$ It is surprising that the legal war on union discrimination is just beginning. Although union power has been nurtured by federal law since 1935, this same body of law did not compel unions to accept Negroes as members until passage of the Civil Rights Act of 1964. Until recently, therefore, the Brotherhood of Locomotive Firemen and Engineers, for one example, could explicitly exclude Negroes from membership without fear of federal sanctions and apparently with full confidence that state law could not be effectively enforced against this plain violation of many state anti-discrimination programs. Apart from membership exclusion, segregated seniority lists and job assignments on a racial basis have not been uncommon. ${ }^{54}$ The reluctance to impose meaningful sanctions on discriminating unions is by no means a thing of the past. Congress went out of its way to protect established seniority rights from the bite of Title VII's provisions, even though these rights may have been acquired as a result of prior discrimination. ${ }^{55}$

The reasons underlying the timidity in attacking union discrimination are not clear. One surely is political. Unions have substantial political power and tend to resist all forms of regulation. Furthermore,

53 E.g., Miranda Fuel Co., 140 N.L.R.B. 181 (1962), enforcement denied 326 F.2d 172 (2d Cir. 1963) (interpreting the Labor-Management Relations Act, 29 U.S.C. \$\$ 141-87 (1964)). I have nothing to add to Professor Sovern's discussion of the impact of the National Labor Relations Act and the Railway Labor Act, 45 U.S.C. $\$$ 151-63 (1964), on racial discrimination by unions. The principle that the use of power granted by the federal government to private groups may be regulated so as to prevent its exercise in what is thought to be an abusive fashion seems to me well established and sound. See Steel v. Louisville \&: N.R.R., 323 U.S. 192 (1944); Wellington, Union Democracy and Fair Representation: Federal Responsibility in a Federal System, 67 YALE L.J. 1342 (1958). Implementation of this principle in particular cases raises questions of congressional intent and administrative discretion which are fully and fairly treated by Professor Sovern.

54 NORGREN \& Hill, op. cit. supra note 8, at 41.

55 See Sovern 70-73. 78 Stat. 255 (1964), 42 U.S.C. § 2000e-2(h) (1964), provides in part: "Notwithstanding any other provision of this subchapter, it shall not be an unlawful employment practice for an employer to apply different standards of compensation, or different terms, conditions, or privileges of employment pursuant to a bona fide seniority . . . system ...."

In discussing Title VII, Senators Clark and Case assured their colleagues that: "Title VII would have no effect on established seniority rights. Its effect is prospective and not retrospective. Thus, for example, if a business has been discriminating in the past and as a result has an all-white working force, when the title comes into effect the employer's obligation would be simply to fill future vacancies on a nondiscriminatory basis. He would not be obliged-or indeed, permitted-to fire whites in order to hire Negroes, or to prefer Negroes for future vacancies, or, once Negroes are hired, to give them special seniority rights at the expense of the white workers hired earlier. (However, where waiting lists for employment or training are, prior to the effective date of the title, maintained on a discriminatory basis, the use of such lists after the title takes effect may be held an unlawful subterfuge to accomplish discrimination.)" 110 CoNG. REc. 7213 (1964). 
one body of opinion holds that because civil rights organizations need the political punch unions can lend them and the political interests of the two groups diverge in only minor fashion, the maintenance of political unity is worth the sacrifice of continued discrimination by unions. ${ }^{56}$ It is probably the case that in fighting discrimination caused by explicit state action such as public school segregation, organized labor has been a substantial political force on the civil rights side, at least at the federal level. But labor's legislative aims are not necessarily consistent with Negro economic advancement. One fixed goal of organized labor's political activities, for instance, is the reduction of lowwage competition, principally through minimum wage laws. Since that competition is quite often from Negro workers, legislation designed to drive them from the labor market is hardly in the interest of Negroes generally. The political alliance with organized labor, therefore, is not as advantageous as it seems to appear to many civil rights organizations.

Another reason for the reluctance to challenge union discrimination is reflected in Professor Sovern's assertion that union power to discriminate is "no rival for that of employers." 57 What this means is not entirely clear. In part it may reflect a Marxist vision of white and Negro workers marching arm in arm against their common enemy, the capitalist. But since the principal economic beneficiaries of discrimination against Negro workers are white workers, rather than white capitalists, ${ }^{58}$ there is no bulwark of common self-interest that would be destroyed by insistence on union observance of non-discriminatory standards. Similarly, at a less esoteric level, a union which controls hiring through restrictions on entry into apprenticeship programs and hiring halls has enormous power to discriminate. ${ }^{59}$ Since the maintenance of a high-wage scale requires the exclusion of potential competitors in any event, economic motive and racial bias combine to bar Negroes entirely from certain jobs. In many cases, therefore, unions, unlike employers, who by definition discriminate effectively only by paying a premium in extra labor cost or less production, often profit from racial discrimination. ${ }^{60}$

56 See SOVERN 144: "The AFL-CIO has been an outspoken supporter of civil rights legislation and its president-George Meany-has been honored by both the NAACP Legal Defense and Education Fund and the National Urban League."

57 Id. at 143 .

58 Becker, The Economics of Discrimination 13-14 (1957).

59 I don't mean to suggest that a necessary function of the hiring hall is exclusion. The traditional weapons of strikes and picketing may be amply adequate for that purpose. And admission to the hiring hall does not necessarily entail assignment to a job.

60 This is not to say unions have no interest in productivity. Plainly they must 
This is not to say that Negroes suffer more from union discrimination than from the employer, unorganized employee, or consumer variety. That is not a resolvable issue. And it is perfectly true that most unions do not seek, either formally or under the table, to control hiring, the most critical stage of the process. But I suspect that if one were to attempt to catalogue the industries from which Negroes are most systematically excluded, they would be those in which unions do control hiring. Since many of these have traditionally served as the pipeline for ethnic group betterment, the labor movement must be held responsible for some of the most pernicious bottlenecks preventing Negro advancement. Professor Sovern's book bears out these observations. He notes, for instance, that in 1961 "most of the unions in Washington, D.G., had no Negroes in their apprenticeship program ... , even though Negroes comprise a majority of the District's population." 61

There is no little irony in the fact that many of these arrangements seem more tractable to legal regulation than employer hiring in a free labor market. Seniority systems, for instance, because they are embodied in contractual provisions resulting from collective bargaining and are not based on economic considerations relating to productivity, can be rearranged so as to erase in a reasonable fashion the results of prior discrimination. Where, for example, separate seniority lists, Negro and white, have been maintained in the past, an agency such as the Equal Employment Opportunity Commission could rearrange them on the basis of length of time with the company or some other suitable principle instead of permitting the parties to put the Negro list at the bottom. ${ }^{62}$ Similar arrangements are possible where Negroes have been entirely excluded because of union pressure, as for example, a prohibition against laying off Negroes for a given period of time. Negroes hired in the first six months after the termination of discriminatory hiring practices might be given superseniority for purposes of layoffs for one, two, or three years, at which time seniority would revert to hiring dates.

Congress' failure to impose such requirements, indeed, its visible exertion to protect seniority rights under Title VII, was based on a misunderstanding of the nature of seniority. Seniority was viewed, by

and do. But they are shielded in part from competition and are thereby able to satisfy other preferences which sacrifice productivity.

61 SOVERN 202.

62 I don't mean to suggest that Title VII necessarily permits the parties to join previously separate seniority lists by putting the Negro list at the bottom. That is not clear. It is clear, however, that Congress went out of its way to render this a permissible interpretation. See SOVERN 72. 
Professor Sovern as well as Congress, as a neutral, non-racial standard which might, like productivity, be permitted to govern employment decisions without conflict with the principle of color-blindness. ${ }^{63}$ But seniority is not like productivity. It is a neutral standard only in the context of collective bargaining between an employer and a union. In that situation it serves as a relatively certain and easily applied criterion which deprives both parties of discretion in the determination of certain delicate employment matters. As such, it is valued more for the certainty it provides than for the results it produces. To the general public, however, such a rule has no value, except perhaps as device to procure labor peace, for it is merely an arbitrary standard which allocates economic benefits on a preferential basis unrelated to qualifications or ability. Indeed, because it sacrifices productivity, ${ }^{64}$ consumers suffer from its implementation, and, for that very reason, seniority systems can generally be effectively imposed only in situations in which a relative degree of monopoly exists, as in collective bargaining. The public, therefore, does not have the same stake in safeguarding a union's seniority system that it has in protecting an employer's freedom to respond to market pressures and to seek the cheapest, most efficient means of production.

Seniority is, moreover, by no means necessarily neutral as to race. In the examples set out above-separate racial seniority lists subsequently merged with the Negroes going to the bottom, or the use of seniority in an employment situation from which Negroes have been deliberately excluded in the past-it is nonsense to pretend that seniority is neutral. It is the dead hand of racial prejudice governing present relationships and is of value to no one except its direct beneficiaries. The argument for permitting its continued existence is based not on some immutable principle of fairness but rather on a fear of antagonizing those beneficiaries and of disrupting established relationships. I have no doubt that such matters might reasonably be taken into consideration. But to strike a different balance here than in situations in which an employer cannot hire Negroes without extra cost can only be the result of paying too much homage to liberal mythology. Seniority is itself a preferential system unrelated to productivity; to condition continued use upon its not being employed to perpetuate the effect of

63 Id. at 71 .

64 This does not mean that seniority is totally inconsistent with productivity. In many instances, seniority may be an accurate barometer of ability. See ReEs, THE EcoNOMICS OF TRADE UNIONS $154-56$ (1962). It does mean, however, that inflexible seniority rules are unlikely to exist for long in a free market and that monopoly is necessary to their survival. 
racial prejudice is not the kind of preferential treatment for Negroes we ought to avoid.

The more difficult problems arise with seniority systems which incorporate standards of productivity. Thus, progression through a system might depend not only on length of time with the employer but also length of time in certain jobs, experience in the easier jobs being necessary to performance on the more difficult. ${ }^{65}$ Under these circumstances, advancement of Negro applicants by decree cannot occur without sacrificing productivity. Rearrangement of seniority systems to eliminate the effects of past discrimination, therefore, ought to occur only within systems based strictly on seniority and not in part on experience and productivity. But even in the cases cited above it would be possible to advance Negroes within job categories although not between them, and steps can be taken to see that Negroes are in fact admitted to the lower categories.

Where unions have control over job assignments through hiring halls and apprenticeship programs, moreover, there seems to be no reason to permit them to apply whatever subjective standards they desire. That such monopoly power ought to be permitted to exist is itself a serious question. That its exercise without adherence to objective and reviewable standards should be prohibited is clear. A combination of an administratively supervised examination, like the Armed Forces Qualification Test, ${ }^{66}$ which distinguishes between kinds of aptitudes, and a lottery, for example, might govern apprenticeship admissions. Since the number to be admitted is usually so small and testing is accurate only within given ranges, a reasonable passing score should first be established, ${ }^{67}$ and then a lottery employed to determine which passing applicants are to be admitted to particular apprenticeship programs. The passing score lottery scheme avoids the danger that the testing will be further distorted as a result of tutoring or other devices which choosing only the top scores for entry would plainly encourage. Another test, again with a reasonable passing score, might be administered at or near the end of the apprenticeship period to insure that the potential demonstrated in the initial test had been realized.

65 See Whitfield v. United Steelworkers of America, Local 2708, 263 F.2d 546 (5th Cir. 1959).

66 Indeed, since many applicants will have taken this particular examination, their scores might be used and the necessity of a reexamination obviated. Only those who have not taken it or have been examined but believe they can improve their scores would be required to take a test.

67 The dominance of nepotism and other such criteria in the past as a means of choosing entrants into these industries hardly suggests any necessity of taking only the top scores. 
Moreover, I see no objection to requiring holders of this power aggressively to seek out applicants from previously excluded groups with a view toward demonstrating that opportunities are now available to qualified applicants. To be sure, this again involves preferential treatment of a kind, but there is little harm in that when imposed on such a monopolistic system. The economic terms are frozen through collective bargaining as is, for practical purposes, the number of permissible participants. And strikes and picketing are always available to enforce these schemes against any employer or non-union employee who seeks to breach them. Temporary preferential treatment under those arrangements is simply not the same as it would be in freer markets where productivity and worker preferences are assigned primary responsibility for job allocation.

The possibility of imposing such controls under existing law is not great. Section 707, for instance, is in some ways suited to the hiring hall problem, permitting as it does the institution of actions by the Attorney General for "such relief ... as he deems necessary" against unions engaging in "a pattern or practice of resistance to the full enjoyment of any of the rights secured by" Title VII. But such actions probably cannot be maintained in the absence of proof of a specific intent to discriminate on racial grounds. Indeed, most anti-discrimination schemes probably require such proof and, in addition, may even prohibit some of the devices suggested, at least to the extent that they involve preferential treatment.

Professor Sovern is plainly right in calling for reform in this area, although he fails to distinguish between preferential treatment which redresses discrimination resulting from the racially biased exercise of monopoly power and similar treatment which sacrifices the neutral standard of productivity. The explicit practices of organized labor which close potential avenues for Negro advancement have been ignored for too long. Our failure even to admit the enormity of the effect of such practices surely lessens the credibility of our efforts to alleviate Negro poverty.

\section{The Federal Contragtor Program}

This program, based on various Executive Orders ${ }^{68}$ and implicitly sanctioned by Title VII of the Civil Rights Act of $1964,{ }^{69}$ is, according to Professor Sovern, both the most effective anti-discrimination program

68 See 41 G.F.R. $\$ \S 60-61$ (1966). Previous orders are described in Sovern 9-17, 104-05.

69 Title VII's requirements as to records and reports contemplate existence of a program although they do not necessarily sanction a program which is, at least in my view, discriminatory. See SOVERN 113-14. 
at present and the one that holds the greatest promise for the future. Were it merely a program compelling employers with specified kinds of government contracts to agree to hire and establish terms and conditions of employment on a racially non-discriminatory basis, it would not merit separate treatment. That sort of a scheme would differ only in detail from the typical anti-discrimination legislation dealt with above and would be little more than a pledge to comply with federal law.

The federal contractor program, however, is a considerably different animal. The relevant contractual language does not, as do other fair employment schemes, merely forbid discrimination. It imposes an "affirmative" duty on the contractor to see that he does not discriminate. Such a pledge seems at first glance a puzzle. The only precise thing one can say about an affirmative duty not to do something is that it is the converse of a negative duty not to refrain from doing something. Beyond this all that is clear is that an imaginative lawyer can take these words and run and run and run. Professor Sovern has the legs.

The nondiscrimination clause includes the contractor's promise to "take affirmative action to ensure that applicants are employed, and that employees are treated during employment, without regard to their race, creed, color, or national origin." Coming as it does right after the contractor's pledge not to discriminate, this language obviously imports something more than the usual statutory duty not to turn a Negro away because of his race when he presents himself. It includes, in addition, the contractor's pledge to make an effort to see that Negroes do present themselves, for training and promotion, as well as for initial employment. Ideally, this pledge should be implemented as Lockheed undertook to implement it in its Plan for Progress. At the very least it would seem to entitle the Secretary to insist that the companies: utilize recruitment sources likely to produce Negro as well as white applicants; study their testing procedures and job requirements to insure that they are not placing unnecessary handicaps in the path of Negroes who really can do the job; and, for firms that have Negro employees, review those employees' personnel files for overlooked indications of eligibility for advancement and training. ${ }^{70}$

Lockheed's implementation of its Plan for Progress, it is worth noting, contained not only pledges of the kind described above but

$70 \mathrm{Id}$. at 142 . 
also a "promise to "make certain that qualified minority group employees are included in supervisory and pre-supervisory training classes and in other classes offered to employees on company time." "71 (The emphasis is Professor Sovern's.) Plainly the contractual provisions, so interpreted, do go far beyond a duty not to discriminate and virtually command affected employers to do whatever is necessary to search for, discover, and hire any Negroes in the particular labor market who seem marginally qualified. Thus, with one stroke of the presidential pen, a program ostensibly aimed at the elimination of racial discrimination in employment begins to appear as a program compelling such discrimination.

The enforcement procedures, moreover, seem particularly apt for that purpose. The procedures available are formidable, for:

[The non-discrimination] clause obliges the contractor to include all of the foregoing conditions in his subcontracts and to do whatever the contracting agency may direct him to do to enforce those conditions.

Primary responsibility for obtaining contractor compliance continues to rest with the contracting agencies, but the Secretary of Labor, like the President's Committee on Equal Employment Opportunity before him, may act on his own whenever he sees fit. A wide range of penalties and sanctions is authorized. The Secretary or the contracting agency may: publish the names of violators; recommend that the Justice Department bring suit to enforce the clause; recommend the institution of proceedings under Title VII of the Civil Rights Act; recommend that the Justice Department bring criminal proceedings to punish "the furnishing of false information to any contracting agency or to the Secretary of Labor"; cancel, terminate, or suspend the contract of a noncomplier; and bar noncompliers from any further contracts. ${ }^{72}$

But the program as envisioned by Professor Sovern does not rely solely on sanctions which must be affirmatively invoked by the enforcement agencies. Government contractors covered by the program, whose business may depend on a continuing flow of such contracts, must file annual reports which provide "statistics on the racial composition of the contractor's work force."'73 Professor Sovern acknowledges a "risk that companies will engage in quota hiring to impress government officials that they are not discriminating . ..." 74 A risk, indeed! These

\footnotetext{
71 Id. at 110 .

72 Id. at 104-05.

73 Id. at 122.

74 Id. at 124.
} 
companies must not only show that they are not discriminating; they must demonstrate that they are making "an effort to see that Negroes do present themselves, for training and promotion, as well as for initial employment," that they are utilizing recruitment sources likely to produce Negro applicants, that their testing procedures and job requirements are not putting "unnecessary" (not discriminatory) handicaps in the path of Negroes who "really can do the job," and that, apparently, they "make certain" that their training classes include qualified Negroes. No lawyer in his right mind will advise that fulfillment of these requirements is convincingly demonstrated by a report indicating less than the "right proportion" of Negroes.

But that is not all. Enforcement need not wait until after a contract is let. Those who rely on a continuing flow of such contracts necessarily endanger more than those agreements under performance. In addition, since reports may be required from bidders who are not at the time subject to the non-discrimination clause, Professor Sovern speculates that "perhaps some hopefuls who do not yet have government contracts are nevertheless implementing fair employment policies in order to be ready when their turn comes." 75 These "hopefuls" are very likely to be disappointed if they have not hired some Negroes, for Professor Sovern tells us that "a contractor can hardly continue to maintain that no qualified Negroes are available when the reports of other contractors in the area show Negroes doing comparable work."'76 And if that is the case, it may also be that a bidder who reports substantially fewer Negroes than his competitors, often the "other competitors in the area," will not be awarded a contract as a result of his "discrimination." Since the contract is of great value, ${ }^{77}$ employment qualifications can be sacrificed, and our "hopefuls" would be well advised to match their competitors, perhaps even outdo them, in implementing a "fair employment practice" program.

To be sure, a program of this character puts Negroes to work but at a substantial cost. The principle of color-blindness in employment is abandoned for the hidden subsidization of Negro hiring by the federal government. Contractors, to gain favor with the contracting agencies and the Secretary of Labor, are forced to hire on racial grounds without regard to qualifications. Once the special interests of racial and ethnic groups in such employment are recognized, will our political leaders have the courage to abandon the program, particularly since it is called a "fair employment practice" program, no matter how little the

75 Id. at 126.

$76 I d$. at 125 .

77 Id. at 141 . 
need for it or how great the sacrifice of principle as well as productivity? The politics of "black power" do not suggest that retrenchment will be as easily accomplished as expansion. Also, much as the awarding of government contracts is an important source of power for local political leaders, local racial leaders may find a source of patronage in private companies through such contracts. The recent Kodak experience, viewed in the context of the federal contractor program, does not suggest that organized racial groups will fail to seize the obvious opportunity. Since a contracting agency would be hard-pressed to grant contracts to a company accused of discrimination by local racial leaders, "approval" of a contractor by such groups may well be ultimately taken as better evidence of a "fair employment program" than an impressive compliance report. And in securing that "approval," employers may discover that which Negroes are hired is more important than whether they are hired. ${ }^{78}$

Public employment has always been a tempting object of racial and ethnic pressure. Many police forces in the Northeast stand as a monument to the shortsightedness of permitting such pressure to have an effect. To compel private employers to be concerned about such matters simply because they have government contracts is foolish. And it is naive to believe the program can be terminated with the elimination of Negro unemployment or cannot be easily extended, e.g., to people of various national origins. Indeed, much of the program is already phrased in terms of "minority groups," and only small changes would be necessary to transform it into a scheme requiring racially and ethnically balanced work forces.

Professor Sovern's only observations on any of these issues are as follows:

Measures of this sort obviously increase employment costs. But the increases are not exorbitant and, presumably, any company that accepts a government contract on these terms sees enough profit in it to justify the extra expense. This means that the government may occasionally have to pay more for the goods and services it buys. It frequently assumes this risk when it uses the procurement power to implement an economic or social policy. ${ }^{79}$

78 The dispute between Kodak and the organization known as FIGHT (Freedom, Integration, God, Honor, Today) did not involve the issue of whether Kodak does or ought to hire Negroes. FIGFiT's demands, if acceded to, would have permitted it to designate the 600 Negroes to be accepted for training and employment by Kodak. See generally Carter, The FIGHT Against Kodak, The Reporter, April 20, 1967, p. 28.

79 SOVERN 142. 
This is in effect an admission that governmental subsidization of racial employment practices is involved. It also raises serious questions about the use of "the procurement power to implement an economic or social policy." The required pledge does not merely command compliance with federal statutory law by federal contractors. Nor do the contracts involved have as their purpose any particular economic or social policy the Executive chooses for a time to favor. They are defense contracts, space contracts, contracts relating to the poverty program, etc. The ostensible purposes are in effect subordinated to other policies determined by the Executive. That such use of the procurement power makes easy prey for special interest groups seems evident. Scrutiny by Congress is avoided as is the clarifying and illuminating adversary debate such consideration would generate. It is a nice question whether the federal contractor program, if offered as explicit legislation, could survive in Congress or command the support of the people.

Once instituted, moreover, such programs are not amenable to challenge as a practical matter. The contractors involved are compensated for compliance, and those who fail to get contracts by reason of noncompliance are bound to realize that fulfillment of the requirements imposed is a cheaper and more certain route of redress than whatever other dubious avenues of appeal may exist. Furthermore, because of the relatively unlimited discretion of the contracting agency, implementation is not subject as a practical matter to the usual procedural restraints such as notice, hearing, and burden of proof. Again, compliance is the only rational course. Professor Kaplan has rightly reminded advocates of this program of its procedural first-cousin, "the industrial loyalty security set-up." 80 The federal contractor program is, therefore, mistaken procedurally as well as substantively and should be terminated.

\section{Negro Poverty and Fatr Employment Legislation}

Those who seek to ameliorate the economic status of the Negro community through laws against discrimination in employment allege that two distinct kinds of economic damage result from such discrimination. The first is a higher rate of unemployment among Negroes than among whites. The second is an income differential between comparable (equally productive) white and Negro labor. Much of the case for vigorous enforcement of fair employment programs rests on the premise that they can-without quotas or preferential systems-eliminate or

80 Kaplan, Equal Justice in an Unequal World: Equality for the Negro-The Problem of Special Treatment, 61 Nw. U.L. REv. 363, 387 (1966). 
substantially reduce this economic damage. It is my contention that this premise is not only unproven but wrong. Negro unemployment need not result from discrimination in employment, and, while an income differential must so result, it is amenable to elimination or reduction only through quota systems.

Racial discrimination by itself cannot cause, and has not caused, longrun unemployment among Negroes. As described in detail above, the impact of racial discrimination in employment, or non-racial discrimination for that matter, is determined by wage rates. Unemployment, in short, results from racial discrimination only when wage rates are not permitted to adjust to the non-monetary preferences of employers, employees, and consumers. If sufficient mobility of employers and workers in labor markets is permitted and fiscal and monetary policies are chosen with a view to the maintenance of tight labor markets, there is no reason for unemployment to be of a racial character.

We have, however, placed substantial restrictions on mobility. The Fair Labor Standards $\mathrm{Act}^{81}$ presently forbids most employers from paying less than $\$ 1.40$ per hour to an employee, a rate which is about to be increased to $\$ 1.60$. Many unions have sufficient power to raise wages in their industries to levels above those which would prevail in a free labor market. These restrictions, if they in fact effectively raise wages, have a dual impact. First, they tend to put a premium on skilled labor and to penalize, through unemployment, the unskilled..$^{82} \mathrm{~A}$ rise in labor costs tends to restrict output and thereby to decrease the demand for labor as well as to encourage the substitution of capital (machines). The less skilled naturally are excluded from the market first. To the extent that particular racial groups or persons living in particular geographic areas have been deprived of the education and experience available to others, minimum wage laws are highly discriminatory. Robert F. Kennedy, in campaigning for the Senate in New York, could hardly argue that a higher national minimum wage was necessary to prevent business from moving to the South if this were not true. ${ }^{83}$ The creation of the Job Corps along with an increase of the minimum wage to $\$ 1.60$ will surely stand as a classic example of one-step-forward, eight-steps-backward economic policy.

But minimum wage laws and union-imposed wage rates have a second

8152 Stat. 1060 (1938), 29 U.S.C. $\$ \$ 201-19$ (1965).

82 I take it there is no serious quarrel over the fact that wages can be raised effectively through union power or minimum wage laws only by causing unemployment. See, e.g., Tobin, On Improving the Economic Status of the Negro, J. AM. ACAD. of Arts \& Saiences 889-90 (1965); Dunlop, Wage Determination Under Trade Unions 32 et seq. (1944).

83 See N.Y. Times, Sept. 10, 1964, p. 26, col. 3; N.Y. Times, Sept. 15, 1964, p. 24, col. 4. 
effect even more directly connected with racial discrimination. By eliminating monetary considerations, they encourage the use of subjective, non-monetary preferences, such as racial prejudice, in the making of economic decisions. ${ }^{84}$ Thus, an employer with a racial animus, the prime target of all anti-discrimination legislation, when faced with a wage rate imposed by a union or a law, is bound to indulge in his bias since it doesn't cost him anything.

The dual impact of restrictions on wage rates is best exemplified by a chapter in Professor Sovern's book consisting of a case study of the apprenticeship program of Local 28, Sheet Metal Workers International..$^{85}$ Because the wage rate for journeymen is so high (in 1963, $\$ 6.15$ per hour plus fringe benefits), there are more applicants for admission to the apprenticeship program than can possibly be accommodated under the going wage scale. An apprenticeship class beginning under court order in 1965, for instance, was to consist of only 65 persons, far below the number of applicants. Since the local's jurisdiction was New York City, the wage rate was probably exclusionary, thus causing underemployment. Beyond that, however, since the wage was fixed at a point which provided more qualified applicants than were needed or could be used, the parties involved, the employers and the union, had no economic grounds upon which to choose between applicants. The result was that $80 \%$ of those admitted to the apprenticeship program were relatives of union members, and Negroes could not gain admittance.

The cure offered by anti-discrimination legislation, as well as by Professor Sovern, is to find a means by which admission to such programs is determined in some objective fashion. As I have argued above, this is a quite proper avenue of attack. But it is a severely limited approach and one which demonstrates the ineffectiveness of anti-discrimination programs as anti-poverty devices. They do not seek to eliminate unemployment; the basic number admitted to the apprenticeship programs, for instance, remains unchanged. They merely allocate unemployment on a non-discriminatory basis. But since Negroes often suffer from inferior education and have fewer skills and less experience than whites, substantial Negro unemployment, relatively more than white, will inevitably survive such programs.

Racial discrimination in employment by itself, therefore, need not cause Negro unemployment, and those who seek to justify anti-discrimination programs on the ground that unemployment is so caused, and can be so cured, are mistaken. And it is a serious mistake, for it affects the character of the programs and the means by which they are enforced.

84 Demsetz, Minorities in the Market Place, 43 N.C.L. Rev. 271, 277-78 (1965).

85 SOVERN 177-85. 
Once it is decided that the elimination of Negro unemployment is a viable goal of these programs, their effectiveness is inevitably determined by the extent to which Negro unemployment is in fact reduced. If that is insubstantial, as it is bound to be, the failure will be attributed to a lack of "teeth," and the demands for more "effective" schemes, such as the federal contractor program, will increase. Therefore, because it is mistaken, the unemployment justification for anti-discrimination programs tends to provide substantial political impetus for preferential systems.

The fact that unemployment is not a necessary result of racial discrimination does not mean, however, that such discrimination inflicts no economic damage upon Negroes. Even in the tightest labor market, a wage differential between comparable Negro and white labor will result from effective market discrimination against Negroes. But this disparity in earnings is unlikely to be amenable to redress by any form of regulation short of quota systems. Because anti-discrimination programs are based on a model of a biased employer, wage differentials between comparable white and Negro labor are prohibited only when they occur within a single firm. Although such circumstances doubtless exist, there is neither rationale nor evidence to indicate they make more than a minimal contribution to the overall disparity in earnings. Many forces in the labor market have in recent years encouraged employers to regularize employment conditions through job classification systems and other devices which tend to discourage such differentials. The influence of collective bargaining and the disturbing effect of such differentials on worker efficiency when imposed in the same plant are among those forces. The disparity in earnings, I suspect, results from inter-firm rather than intra-firm differentials. Because Negroes often prefer to work with other Negroes more than whites do-or whites often prefer to work with Negroes less than Negroes do-there are substantial pressures toward segregated working forces. ${ }^{86}$ Not totally segregated, to be sure, but with racial characteristics inconsistent with the random distribution indifference to race would produce. I am not suggesting that white workers always walk off the job simultaneously with the hiring of Negroes. But over time a sorting out of the kind described will occur if workers have different racial preferences. And if we maintain a tight labor market, which is essential to the economic betterment of Negroes, the preferences of workers, whether racial or not, will tend to have a great impact. Therefore, to the extent that people do have racial preferences, and the widespread existence of 
such preferences is a premise of anti-discrimination laws, the maintenance of a tight labor market may encourage relatively segregated work forces. That, in turn, insures that the wage differential between comparable white and Negro labor will be largely inter-firm rather than intra-firm and not amenable to the legal redress available under antidiscrimination programs. Elimination of the disparity between Negro and white earnings which results from discrimination is, therefore, possible only through quotas.

Relative degrees of segregation among work forces, however, do not necessarily result in such a wage differential. To the extent that Negro labor is substitutable for the factors which prefer not to work with it, a wage differential generally will not result, ${ }^{87}$ for employers will have as much incentive to avoid that factor as to avoid hiring Negroes. But relative segregation will result. Where a complementary factor has a racial preference, however-such as biased foremen preferring allwhite work forces or biased work forces preferring white foremeneffective discrimination and a wage differential will result, because the cost of hiring Negroes will be higher than the cost of hiring whites for an employer who must use the complementary factor. ${ }^{88}$

These observations have great significance for the role of law in alleviating economic hardship among Negroes, a significance which may put advocates of fair employment programs to a cruel choice. Unless quota or other preferential systems are established, Negroes may be better off economically if we let the racial preferences of employees and consumers operate freely, even though relative degrees of segregation in work forces may result. To seek integration through laws compelling employers to be color-blind adds costs to production and thereby lowers total production, total income, and total employment. The goal ought to be to make Negro labor more substitutable for white labor; and that, I believe, is best accomplished by employing Negro labor in its most productive capacities. It means, in short, that the work qualifications of Negroes must be increased, and it means further that Negro unemployment must be eliminated. Employment itself provides the best training, experience, and sense of discipline. It also provides a means of challenging erroneous judgments based on stereotypy by demonstration and allows individuals to build work records which permit individual assessment. But the goal of eliminating Negro unemployment is not necessarily consistent with fully integrated work forces and is certainly

87 Becker, The Economics of Discrimination $48-53$ (1957).

88 This is one reason employers are often viewed as the main source of employment discrimination, for they are the most complementary factor and their grave counterincentives are overlooked. 
inconsistent with the maintenance of inflexible and artificial wage rates which restrict the mobility of labor.

The alternative is some form of preferential treatment. It is not a purpose of this article to evaluate such an approach. It has been sympathetically, if not favorably, dealt with in detail elsewhere. ${ }^{89}$ That such an approach involves great costs must be noted, however. There is, first, the problem of determining the shape and scope of a program of preferential treatment. As I suggest above, the most effective kind might well entail extensive coercion of Negroes in their choice of jobs and areas in which they want to work. Just as racial discrimination against Negroes has victims, so also will discrimination in favor of them. And it is unlikely that these new victims will be better able to afford it than are Negroes. Nor does experience with preferential programs-with farmers, for instance-indicate there is much hope of termininating them at the appropriate time no matter how temporary everyone proclaims them to be when they are initiated.

In any event, preferential programs are fundamentally countereducative on the basic issue of racial discrimination itself. Instead of helping to eliminate race from politics, they inject it. Instead of teaching tolerance and helping those forces seeking accommodation, they divide on a racial basis. Such programs tend to legitimate the back-lash by providing it with much of the philosophical and moral base from which the civil rights movement itself began. And, indeed, there is no reason to believe that if racial issues become more, rather than less, of a political issue, Negroes will be the winners.

The costs of preferential programs, moreover, are far more certain than the gains. The very demands for such programs have already created a reaction along the lines described above. It would be a tragedy to pay all the costs of preferential treatment and to learn that it was not as effective as had been hoped. Certainly such programs ought to be considered last resorts if not altogether too dangerous.

But unless anti-discrimination programs are to operate as preferential systems, they have little to offer as coercive law. As suggested earlier, such laws do have an educative and moral impact which in many ways attacks the problem directly without resort to invidious devices such as quotas. But limiting the impact of law to its educative value is a tricky matter not so much because of the attitude of those whose conduct we are trying to change as because of the attitude of those whom we are trying to help. For if the advocates and beneficiaries of such laws do not understand their limited purpose, it may be better to avoid a legislative

89 See generally Kaplan, supra note 80 . 
approach entirely. We are relatively unpracticed at using law as a moral symbol rather than a coercive device. Legislatures are looked to for regulation which results in concrete accomplishments, not moral leadership. If accomplishments are not forthcoming-and gains achieved through the symbolic value of law are never highly visible-the motives of those responsible for enforcement will be questioned, and the demands for laws with "teeth" will increase. By then political pressures may be created which do not permit a viable solution of the underlying problems.

Laws against discrimination in employment have created such a dilemma. Too much has been expected from anti-discrimination programs, and the relevant political forces have done nothing to dampen these expectations. The adoption of laws against discrimination in employment has itself been taken as evidence that such discrimination causes poverty which can be substantially reduced through law. And the inevitable failure to achieve that reduction has caused disrespect for law and further Negro alienation and frustration. The authorities, meanwhile, have been distracted from the real causes of the problem and have turned to undesirable, but "effective," measures, such as the federal contractor program. Such devices must involve preferential treatment and are, therefore, in the long run counter-educative on the basic issue of the morality of racial discrimination. The officials in charge, moreover, are under pressure to be devious about the nature of these programs, a fact which makes criticism possible only at the risk of being charged with racism or indifference to Negro poverty, much as some of these same officials attribute dissent during a war to a lack of patriotism. The rhetoric of the debate itself thus tends to prevent a rational consideration of the underlying problems. Most important, American politics is not diverted from the disastrous course of restricting the mobility of labor through artificial price supports and attempting to end Negro unemployment by legislation against discrimination..$^{90}$ The educative impact of anti-discrimination programs is not, therefore, unidirectional. What they teach in the way of tolerance is matched by their ability to mislead as to the causes and remedies for Negro poverty. That is the lesson of Professor Sovern's book.

90 Cf. Schlesinger, A Thousand Days 930-31 (1965). 